\title{
Radioreceptor assays: plasma membrane receptors and assays for polypeptide and glycoprotein hormones
}

\author{
Dennis Schulster \\ Biochemistry Laboratory, School of Biological Sciences, University of Sussex, \\ Falmer, Brighton, U.K.
}

\begin{abstract}
Summary. Receptors for peptide, protein and glycoprotein hormones, and the catecholamines are located on the plasma membranes of their target cells. Preparations of the receptors may be used as specific, high-affinity binding agents for these hormones in assay methodology akin to that for radioimmunoassay. A particular advantage of the radioreceptor assay is that it has a specificity directed towards the biologically active region of the hormone, rather than to some immunologically active region that may have little (or no) involvement in the expression of hormonal activity. Methods for hormone receptor preparation vary greatly, and range from the use of intact cells (as the source of hormone receptor) to the use of purified or solubilized membrane receptors. Receptors isolated from plasma membranes have proved to be of variable stability, and may be damaged during preparation and/or storage. Moreover, since they are present in relatively low concentration in the cell, their preparation in sufficient quantity for use in a radioreceptor assay may present technical problems. In general, there is good correlation between radioreceptor assays and in-vitro bioassays; differences between results from radioreceptor assays and radioimmunoassays are similar to those noted between in-vitro bioassays and radioimmunoassays. The sensitivity of the method is such that normal plasma concentrations of various hormones have been assayed by this technique.
\end{abstract}

\section{Introduction}

Hormones and many other biological molecules have in recent years been measured by various types of competitive assays involving displacement of radioactive ligands. This technique of saturation analysis (Ekins, 1974) or competitive protein-binding (Odell \& Daughaday, 1971) has been most widely documented for the radioimmunoassay system (Yalow \& Berson, 1971; Sönksen, 1974) which utilizes an antibody to the hormone as the binding protein. The procedure readily allows the assay of a large number of samples and, by careful selection of antisera, specific and very sensitive measurements are possible. However, important disadvantages of this technique include the immunological rather than biological basis for the binding specificity and the rather long incubation periods (1-7 days) generally reported for sensitive assay systems. Similarly, in competitive binding-protein assays (Murphy, 1968) which utilize other biological macromolecules (such as serum binding proteins instead of antibodies, those structural properties of the binding-protein that dictate the binding parameters are not necessarily related in any way to those needed for expression of the accepted biological activity. Recently, radioreceptor assays for hormones have been developed in many different laboratories, and the particular appeal of this technique is that the entity utilized for binding the hormone is its specific receptor derived from the target cell itself; this has important theoretical advantages relating to assay specificity.

The first hormonal assay employing a cellular receptor was that of Korenman (1968) which utilized an oestrogen-binding protein, derived from rabbit uterine cytosol, for the measurement of oestrogen in plasma extracts (Korenman \& Sanborn, 1971). Receptor proteins which bind other steroid hormones have been identified in the cytoplasmic and nuclear compartments of their respective target cells (King \& Mainwaring, 1974; Schulster, Burstein \& Cooke, 1976), and may be similarly employed in steroid hormone receptor assays. Other biological molecules may be assayed by this 
approach. For example, a sensitive cyclic AMP assay has been developed by using a cytoplasmic binding protein isolated from bovine skeletal muscle (Gilman, 1970) or from bovine adrenal cortex (Brown, Albano, Ekins, Sgherzi \& Tampion, 1971). However, most interest in the radioreceptor methods has been directed towards their application to the assay of polypeptide and glycoprotein hormones utilizing receptors located in the plasma membrane.

\section{Plasma membrane receptors}

The initial interaction between a hormone and its target cell is the binding of the hormone molecule to a specific component of the cell, termed the 'hormonal receptor', which subsequently functions to activate cellular machinery for the hormonal response. It is these receptors that discriminate for the biologically active molecule and thereby determine the specificity of the system for hormone-target cell response.

Hormones may be broadly divided into two main classes. Firstly, there are those that act via receptors located in the outer membrane of the cell and are believed to function by activating plasma membrane-bound adenylate cyclase, with cyclic AMP acting as an intracellular secondary messenger (Robison, Butcher \& Sutherland, 1971). The peptide, protein and glycoprotein hormones and the catecholamines fall into this category and the biochemical events involved in the actions of these hormones have been surveyed (Iversen, 1973; Parsons, 1976; Catt \& Dufau, 1976; Schulster et al., 1976). Secondly, there are the steroid and thyroid (iodothyronine) hormones, which have receptors located in the cytoplasm and/or nucleus of the cell. The present discussion relates only to methods utilizing the plasma membrane-bound receptors.

The arrangement of the receptors within the plasma membrane is unknown, but current concepts envisage a mosaic, or patchwork arrangement for the lipid and protein components of the membrane. It is suggested that some proteins are bound on the inner and outer surfaces of the phospholipid bilayer, some are partly embedded within the hydrophobic region of this bilayer, while others span the bilayer from the inner to the outer surfaces (Singer, 1976). A fuller understanding of the arrangement and functioning of the receptors within the membrane will assist the development of refinements in radioreceptor assay methodology, and much current research is devoted to this task.

Several models of the hormone-membrane receptor-adenylate cyclase system have been suggested. In the model proposed by Perkins (1973) and extended by Cuatrecasas (1974, 1975), the receptors and adenylate cyclase enzymes are envisaged as separate entities which associate (thereby activating the enzyme) by lateral diffusion through the plasma membrane after the hormone has bound to the receptor. Levitzki (1974) has suggested another model system, relating to the phenomenon of negative cooperativity, in which the binding of hormone to one receptor (organized within a stable oligomeric cluster) induces conformational changes in the bound receptor and its neighbours; a molecular explanation thus being provided for the 'spare receptors' observed in many binding-response studies. In contrast to the static clustering proposed by the Levitzki model, a dynamic clustering of receptors within a fluid mosaic membrane has also been suggested to account for negative cooperative binding (Singer, 1976).

Several workers have attempted to elucidate the functional complexity of this system, the activity of which can be modulated at three or more different loci (Rodbell et al., 1975). These are (i) the hormone-receptor site, (ii) a nucleotide regulatory site which interacts preferentially with guanyl nucleotides (a GTPase), and (iii) the catalytic site which converts ATP, chelated to magnesium, into cyclic AMP.

Despite the complexity of the biological mechanism and our limited understanding of it, the important feature to note for the purposes of this discussion is that the binding of hormones to membrane receptors is rapid, saturable and reversible (Clark, Klee, Levitzki \& Wolf, 1976). The receptors have two important functions: (i) initially to bind with a high degree of specificity to particular molecules, thereby discriminating the hormone from other blood-borne components, and (ii) to activate the biological cellular response when bound to the hormone. The radioreceptor assay relates only to the former of these two functions. 


\section{Correlations between radioreceptor assays and other methods}

\section{Bioassays}

The potency measured by the traditional in-vivo bioassay technique assesses the overall effect and incorporates a multiplicity of biological events: from absorption at the injection site and dispersion in the blood, through effects on blood-flow rate and variations in hormonal inactivation or degradation, as well as hormone-receptor binding and the intracellular events in the target cell that lead to full expression of the biological response. In the in-vivo bioassay, the affinity of hormone and receptor is likely to assume a relatively minor and quantitatively less important role than all the other combined events.

By comparison, bioassay methods in vitro incorporate fewer of the above events in the assessment. They provide a simpler system, the results of which are considerably more dependent upon the affinity of hormone and receptor. This accounts for the good correlation usually observed between radioreceptor assays and in-vitro bioassays and the often poor correlation with in-vivo bioassays.

Although radioreceptor assays correlate well with in-vitro bioassays, it should be emphasized that the two assays provide different information and can give quite different results. For example, some hormone analogues or metabolites may be able to bind to the receptor, but have no (or limited) capability to activate the cellular biological response. These molecules would register in the radioreceptor assay but hardly at all in the bioassay. By contrast, some molecules can by-pass the normal hormone-receptor mechanism and stimulate the target-cell response at some other intracellular locus. Thus, in various cells it is possible to activate the biological response usually associated with a specific hormone by a wide variety of other agents, including, for example, cholera toxin (Bennett \& Cuatrecasas, 1975), cyclic AMP and methylxanthines (Robison et al., 1971), polylysine (Wolff \& Cooke, 1975), potassium ions (Muller, 1971; Tait, Tait \& Bradley, 1972) and prostaglandins (Shaw \& Tillson, 1974; Sammuelsson Granström, Green, Hamberg \& Hammerström, 1975). Such substances would register in the bioassay, but pass undetected in the radioreceptor assay.

It is therefore essential, when documenting results, to note the assay methodology; definitive interpretation requires comparison of results from different methods. Radioreceptor assays determine the hormone's ability to interact with its receptor-information which is valuable, but different from that obtained by bioassay.

\section{Radioimmunoassay and other competitive binding assays}

The special properties of antibodies which have encouraged their wide and ever-increasing use in radioimmunoassays are their high affinity and considerable specificity for their antigen (e.g. hormone). Other binding proteins with these properties have been similarly used in competitive binding assays. However, the prime advantage of the cellular hormone receptor for such an assay is that its binding specificity is directed towards those regions of the hormone in which the biological activity resides, rather than to some immunologically active region of the hormone or another binding region with little, if any, involvement in expression of the biological activity. In in-vitro bioassays and radioreceptor assays, the same structural features of the hormone contribute towards the results, and they often correlate well. Although radioimmunoassays, and other competitive binding assays, rely predominantly on other properties of the hormone molecule, and their results correlate less frequently with those of bioassays and radioreceptor assays, comparison of results has often provided valuable information.

\section{Gonadotrophins}

Receptor sites for LH and HCG have been demonstrated in the testis and the ovary. The preparation of radioactive gonadotrophins and of particulate gonadal receptors, together with the detailed methodology for LH and HCG radioreceptor assays, have been reviewed (Catt \& Dufau, 1975; Dufau \& Catt, 1976). Simple homogenates of decapsulated rat testis are centrifuged at $1500 \mathrm{~g}$ for 15 min to sediment most of the binding particles. After resuspension, these particles can be stored as 
frozen aliquots for several weeks without great loss of binding activity. Each rat testis provides sufficient receptor preparation for 50-80 assay samples. Such receptors have high affinity $\left(K_{a}=1\right.$ $2 \times 10^{10} \mathrm{M}^{-1}$ ) for LH and HCG. The presence of tubular elements in the homogenates did not appear to interfere with the interstitial-cell binding of gonadotrophins. For the radioreceptor assays, aliquots of the $1500 \mathrm{~g}$ preparation are incubated $\left(16-24 \mathrm{~h}, 24^{\circ} \mathrm{C}\right)$ and receptor-bound and free hormone can be subsequently separated by centrifugation $(1500 \mathrm{~g}, 15 \mathrm{~min})$ or by filtration through glass-fibre discs. Sensitivities of $0.1 \mathrm{ng} \mathrm{HCG}$ per assay vial $(0.2 \mathrm{ml})$ can be achieved and the assay slopes of HCG and LH are parallel. For determinations of plasma gonadotrophins, preliminary extraction by adsorption to Sepharose-Concanavalin A is to be recommended (Dufau, Tsuruhara \& Catt, 1972).

Resuspended particles of the $1500 \mathrm{~g}$ fraction derived from homogenates of ovarian tissue from pseudopregnant rats (pretreated with PMSG and HCG) have also been used to provide a radioreceptor assay for gonadotrophins (Lee \& Ryan, 1973).

A tissue preparation from rat testes has similarly been used in an FSH radioreceptor assay (Reichert \& Bhalla, 1974): a detection limit of about $2.5 \mathrm{ng}$ pure FSH was obtained and there was an excellent correlation (mean index discrimination: 1.05) for a series of different human FSH samples between the radioreceptor assay and an in-vivo bioassay. Although this radioreceptor assay is not to be recommended for measuring the FSH content of highly purified human LH or TSH, it would appear to be a useful and specific assay for FSH in samples other than these. Partly purified plasma membranes $(100,000 \mathrm{~g}$ pellet with $0.3 \mathrm{M}$-sucrose-tris- $\mathrm{HCl}$ buffer) from bovine test is have also been used to establish an FSH radioreceptor assay applicable to its measurement in serum (Cheng, 1975). The sensitivity of this assay for serum samples was about $2.5 \mathrm{ng} \mathrm{FSH} / \mathrm{ml}$, and was specific for FSH of various species: other protein and polypeptide hormones (including high concentrations of $\mathbf{L H}$ and HCG) did not interfere. There was good correlation between radioimmunoassay (RIA) and radioreceptor assay (RRA) data for human serum FSH (mean index discrimination RIA/RRA = 1.08), but for the FSH content of human anterior pituitary extracts the agreement was poor (mean index discrimination RIA/RRA $=1.7$ ) and similar to that found by others for the RIA : bioassay ratio.

\section{Insulin, growth hormone and prolactin}

A number of methods have been reported for the assay of these hormones: the receptor protein has been obtained from rabbit mammary tissue (Shiu, Kelly \& Friesen, 1973), pregnant rabbit liver membranes (Tsushima \& Friesen, 1973; Sneid, Jacobs, Weldon, Trivedi \& Daughaday, 1975), purified liver membranes (Gavin, Kahn, Gorden, Roth \& Neville, 1975) and intact cultured human lymphocytes (Roth, 1975; Gavin et al., 1975).

Although their biological functions are unclear, receptors for insulin and growth hormone have been detected on human lymphocytes and assay methods have been developed for these hormones by utilizing whole suspended lymphocytes (IM-9 cultures) as a receptor source (Roth, 1975). This technique has advantages over the use of broken cell or purified membrane preparations, in that the latter have considerably higher hormone and receptor degrading capabilities, and, moreover, require much greater care in the preparation of batches to give reproducible results. In this assay, lymphocytes were incubated with hormone (radioactive and unknown sample) for $90 \mathrm{~min}$ at $30^{\circ} \mathrm{C}$ (growth hormone) or $15^{\circ} \mathrm{C}$ (insulin; to minimize degradation and increase specific binding) and centrifuged at high speed to obtain a cell pellet. The radioactivity in the pellet was then counted to determine the percentage of bound hormone. In the absence of non-radioactive hormone, binding achieved steady state conditions after $90 \mathrm{~min}$, when about $12 \%$ of the radioactivity was bound. 'Non-specific binding'-measured in the presence of excess non-radioactive hormone $(10 \mu \mathrm{g} / \mathrm{ml})$-was approximately $1 \%$. A decrease in 'specific binding' from 11 to $10 \%$ was observed in the presence of $2 \mathrm{ng} \mathrm{HGH} / \mathrm{ml}$ $\left(\sim 10^{-10} \mathrm{M}\right)$ or $1 \mathrm{ng}$ insulin/ml, i.e. resting concentrations of the hormones in vivo, and the specificity of binding was in accordance with other biological activity studies.

With a receptor preparation derived from the $15,000-100,000 \mathrm{~g}$ pellet of liver membranes from pregnant rabbits, Sneid et al. (1975) have described a method for the measurement of GH levels in normal human beings (best assay sensitivity $=0.66 \pm 0.30 \mathrm{ng} \mathrm{GH} / \mathrm{ml}$ serum; incubation $=16 \mathrm{~h}$ at 
room temperature). No significant discrepancy was found between the results from the radioimmunoassay and the radioreceptor assay for basal samples from normal subjects $(1.9 \pm 0.3 \mathrm{ng} / \mathrm{ml})$. However, $1.5 \mathrm{~h}$ after administration of human GH secretagogues, a marked discrepancy appeared (RIA/RRA $=1 \cdot 8 \pm 0.2$ ) which was attributed to the presence of immunologically active, but biologically nonfunctional, molecules in the serum. These might arise either directly by secretion from the stimulated pituitary or indirectly via peripheral metabolism of secreted human GH.

In a radioreceptor assay for insulin with rat liver membranes, Gavin et al. (1975) found that porcine pro-insulin, insulin and closely related preparations inhibit binding in the same rank order as their biological activity, and that these molecules have identical specificities in the rat liver membrane and human lymphocyte assays.

\section{Corticotrophin and angiotensin II}

The first report of the use of target tissue receptors for polypeptide hormone assay was that of Lefkowitz, Roth \& Pastan (1970) for corticotrophin (ACTH). Receptors were prepared from homogenates of an ACTH-responsive mouse adrenal tumour; $4000 \mathrm{~g}$ and $10,000 \mathrm{~g}$ pellets were freeze dried, added to an emulsion of phosphatidylethanolamine, passed through a French Pressure cell and after discarding the $105,000 \mathrm{~g}$ pellet, the dialysed clear supernatant was used as a solubilized ACTHreceptor preparation. Receptor preparations for ACTH have also been derived from normal sheep, rabbit or rat adrenal glands (Wolfsen, McIntyre \& Odell, 1972) and freshly obtained ox adrenals (McIlhinney \& Schulster, 1973).

Wolfsen et al. (1972), using an anion-exchange resin (Rexyn) to separate free from bound hormone, found the useful range of their assay to operate from 1-10 pg ACTH $/ 0.1 \mathrm{ml}$ plasma sample, and that it was possible to measure reproducibly ACTH in $0.25 \mathrm{ml}$ unextracted plasma from normal human beings $(54-75 \mathrm{pg} / \mathrm{ml})$. However, methods involving solubilization of receptors with phosphatidylethanolamine and the French Pressure cell are awkward, and in other laboratories have been found to be of variable reproducibility. Future methodology may profitably employ receptors on whole isolated adrenal cells (McIlhinney \& Schulster, 1975) as has been done with insulin and GH by using whole lymphocytes.

Subcellular particles $(20,000 \mathrm{~g})$ from bovine adrenal cortex have also been used in a radioreceptor assay for angiotensin II and its analogues (Saltman, Baukal, Waters, Bumpus \& Catt, 1975). Incubations were at $20^{\circ} \mathrm{C}$ for $20 \mathrm{~min}$ and receptor-bound hormone was separated by filtration through nitrocellulose Millipore filters. This assay provides a valuable method for comparing the relative binding affinities of different angiotensin II analogues. However, normal resting plasma concentrations of angiotensin II are between 2 and $5 \times 10^{-11} \mathrm{M}$, and this radioreceptor assay is only capable of measuring hormone concentrations 100 - to 1000 -fold more concentrated than this. It may be predicted that a considerably more sensitive assay would be obtained by utilizing adrenal capsular tissue (glomerulosa cells) as a receptor source because these are the target cells for angiotensin II (Douglas, Saltman, Fredlund, Kondo \& Catt, 1976; Bing \& Schulster, 1976).

\section{Other hormones}

Radioreceptor assays for many of the other peptide, protein and glycoprotein hormones are now appearing in the literature. Space does not permit a complete survey of these methods, but of interest are studies on the hypothalamic releasing hormones (Grant \& Vale, 1975), parathyroid hormone (Sutcliffe, Martin, Eisman \& Pilczyk, 1973), somatomedin (Hall, Takano, Fryklund \& Sievertsson, 1975) and thyroid-stimulating hormone (Amir, Carraway, Kohn \& Winand, 1973; Verrier, Fayet \& Lissitzky, 1974).

This assay method has been of particular use with those molecules for which specific receptors have been located but for which no radioimmunoassay is available, such as the non-suppressible insulin-like activity (Megyesi, Kahn, Roth \& Gorden, 1974).

Other relevant information may be obtained from the articles by Kahn (1974), Blecher (1976) and Parsons (1976). 
This manuscript was prepared during the tenure of an EMBO long-term fellowship award, and a Lady Davis Fellowship at the Hebrew University of Jerusalem, to whom grateful thanks are extended.

\section{References}

Amir, S.M., Carraway, T.F., Kohn, L.D. \& Winand, R.J. (1973) The binding of TSH to isolated thyroid plasma membranes. J. biol. Chem. 248, 4092-4100.

Bennett, V. \& Cuatrecasas, P. (1975) Mechanism of action of vibrio cholerae enterotoxin. J. Membrane Biol. 22, 1-28.

BiNG, R.F. \& Schulster, D. (1976) Steroidogenesis in isolated rat adrenal glomerulosa cells: response to physiological concentrations of angiotensin II and effects of potassium, serotonin and $\mathrm{Sar}^{1} \mathrm{Ala}^{8}$ angiotensin II. J. Endocr. (in press).

Blecher, M. (Ed.) (1976) Methods in Receptor Research. Marcel Dekker Inc., New York.

Brown, B.L., Albano, J.D.M., Ekins, R.P., Sgherzi, A.M. \& Tampion, W. (1971) A simple and sensitive saturation assay method for the measurement of adenosine $3^{\prime}, 5^{\prime}$ cyclic monophosphate. Biochem. $J$. 121, 561-562.

CATr, K.J. \& DufaU, M.L. (1975) Gonadal receptors for luteinizing hormone and chorionic gonadotrophin. In Methods in Enzymology, Vol. 37, Part B, pp. 167-193. Eds B. W. O'Malley \& J. G. Hardman. Academic Press, New York.

Catr, K.J. \& Dufau, M.L. (1976) Basic concepts of the mechanism of action of peptide hormones. Biol. Reprod. 14, 1-15.

Cheng, K.-W. (1975) A radioreceptor assay for folliclestimulating hormone. Endocrinology 41, 581-589.

Clark, J.H., KleE, W., Levitzki, A. \& WolfF, J. (Eds) (1976) Hormone and antihormone action at the target cell. Life Sciences Research Report No. 3. Dahlem Konferenzen, Berlin.

Cuatrecasas, P. (1974) Membrane receptors. A. Rev. Biochem. 43, 169-214.

Cuatrecasas, P. (1975) Hormone receptors-their function in cell membranes and some problems related to methodology. Adv. cyclic Nucleotide Res. 5, 79-104.

Douglas, J., Saltman, S., Fredlund, P., Kondo, T. \& CATT, K.J. (1976) Receptor binding of angiotensin II and antagonists. Correlation with aldosterone production by isolated canine adrenal glomerulosa cells. Circulation Res., Suppl. II, 38, 108-112.

Dufau, M.L. \& CATT, K.J. (1976) Gonadal receptors for luteinizing hormone and chorionic gonadotrophin. In Cell Membrane Receptors for Viruses, Antigens and Antibodies, Polypeptide Hormones and Small Molecules, pp. 135-163. Eds R. F. Beers \& E. G. Bassett. Raven Press, New York.

Dufau, M.L., Tsuruhara, T. \& CatT, K.J. (1972) Interaction of glycoprotein hormones with agarose concanavalin A. Biochim. biophys. Acta 278, 281292.

Ekrns, R.P. (1974) Basic principles and theory. In Radioimmunoassay and Saturation Analysis, pp. 3-11. Ed. P. H. Sönksen. (Br. med. Bull. 30.)
Gavin, J.R., Kahn, C.R., Gorden, P., Roth, J. \& NEVILLE, D.M. (1975) Radioreceptor assay of insulin, comparison of plasma and pancreatic insulins and proinsulins. J. clin. Endocr. Metab. 41, 438-445.

GilmaN, A.G. (1970) A protein binding assay for adenosine 3'5' cyclic monophosphate. Proc. natn. Acad. Sci. U.S.A. 67, 305-312.

GRanT, G. \& VAle, W. (1975) Pituitary receptor binding assay of hypothalamic releasing factors. In Methods in Enzymology, Vol. 37, Part B, pp. 213-219. Eds B. W. O'Malley \& J. G. Hardman. Academic Press, New York.

Hall, K., Takano, K., Fryklund, L. \& Sievertsson, H. (1975) The measurement of somatomedin A by radioreceptor assay. Adv. Metabolic Disorders 8, 6171.

IVERSEN, L.L. (Ed.) (1973) Catecholamines. Br. Med. Bull. 29, 91-178.

KAHN, C.R. (1974) Membrane receptors for polypeptide hormones. In Methods in Membrane Biology, Vol. 3, pp. 81-146. Ed. E. D. Korn. Plenum Press, New York.

KING, R.J.B. \& MaINWARING, W.I.P. (1974) SteroidCell Interactions. Butterworths, London.

KoRENMAN, S.G. (1968) Radioligand binding assay of specific oestrogens using a soluble uterine macromolecule. J. clin. Endocr. Metab. 28, 127-130.

Korenman, S.G. \& SANBORN, B.A. (1971) Hormonal assays employing tissue receptors. In Principles of Competitive Protein-Binding Assays, pp. 89-103. Eds. W. D. Odell \& W. H. Daughaday. Lippincott, Philadelphia.

Lee, C.Y. \& Ryan, R. (1973) Luteinizing hormone receptors: specific binding of human luteinizing hormone to homogenates of luteinized rat ovaries. Proc. natn. Acad. Sci. U.S.A. 69, 3520-3523.

Lefkowitz, R.J., Roth, J. \& Pastan, I. (1970) Radioreceptor assay of adrenocorticotrophic hormone. New approach to assay of polypeptide hormones in plasma. Science, N.Y. 170, 633-635.

LevitzKI, A. (1974) Negative cooperativity in clustered receptors as a possible basis for membrane action. J. theoret. Biol. 44, 367-372.

McIlhinney, R.A.J. \& Schulster, D. (1973) Adrenocorticotrophin assay, using a radioreceptor method and a bioassay involving isolated adrenal cells, for studies on isolated anterior pituitary cells. J. Endocr. 57, xlvi-xlvii.

MCIlHINNey, R.A.J. \& Schulster, D. (1975) Studies on the binding of ${ }^{125}$ I-labelled corticotrophin to isolated rat adrenocortical cells. J. Endocr. 64, 175184.

Megyesi, K., Kahn, C.R., Roth, J. \& Gorden, P. (1974) Hypoglycemia in association with extrapancreatic tumors: demonstration of elevated 
plasma NSILA-s by a new radioreceptor assay. J. clin. Endocr. Metab. 38, 931-934.

Muller, J. (1971) Regulation of aldosterone biosynthesis. In Monographs on Endocrinology Vol. 5. Springer Verlag, Berlin.

MurPhy, B.E.P. (1968) Protein binding and its application in the assay of non-antigenic hormones: thyroxine and steroids. In Radioisotopes in Medicine: In Vitro Studies. Eds R. L. Hayes, F. A. Goswitz \& B. E. P. Murphy. U.S. Atomic Energy Commission Division of Technical Information, Washington. (Symposium Series No. 13).

Odell, W.D. \& Daughaday, W.H. (Eds) (1971) Principles of Competitive Protein-Binding Assays. Lippincott, Philadelphia.

Parsons, J.A. (Ed.) (1976) Peptide Hormones. Macmillan Press, London.

Perkins, J.P. (1973) Adenyl cyclase. Adv. cyclic Nucleotide Res. 3, 1-64.

Reichert, L.E. \& Bhalla, V.K. (1974) Development of a radioligand tissue receptor assay for human follicle-stimulating hormone. Endocrinology 94, 483-491.

Robison, G.A., Butcher, R.W. \& Sutherland, E.W. (1971) Cyclic AMP. Academic Press, New York.

Rodbell, M., Lin, M.C., Salomon, Y., Londos, C., HaRwoOd, J.P., Martin, B.R., Rendell, M. \& BERMAN, M. (1975) Role of adenine and guanine nucleotides in the activity response of adenylate cyclase systems to hormones. Evidence for multisite transition states. Adv. cyclic Nucleotide Res. 5, 3-29.

RoTh, J. (1975) Assay of peptide hormones using cell receptors: application to insulin and to human growth hormone. In Methods in Enzymology, Vol. 37, pp. 66-81. Eds B. W. O'Malley \& A. R. Means. Academic Press, New York.

Saltman, S., Baukal, A., Waters, S., Bumpus, F.M. \& CATT, K.J. (1975) Competitive binding activity of angiotensin II analogues in an adrenal cortex radioligand-receptor assay. Endocrinology 97, 275282.

Sammuelsson, B., Granström, E., Green, K., HamBERG, M. \& HAMmerströM, S. (1975) Prostaglandins. A. Rev. Biochem. 45, 669-695.

Schulster, D., Burstein, S. \& CoOke, B.A. (1976) Molecular Endocrinology of the Steroid Hormones. Wiley \& Sons, London.

Shaw, J. \& Tillson, S.A. (1974) Interactions between the prostaglandins and steroid hormones. In Steroid Biochemistry and Pharmacology, Vol. 4, pp. 189-207. Eds M. H. Briggs \& G. Christie. Academic Press, London.

Shiu, R.P.C., Kelly, P.A. \& Friesen, H.G. (1973) Radioreceptor assay for prolactin and other lactogenic hormones. Science, N.Y.180, 968-971.

SINGER, S.J. (1976) The fluid mosaic model of membrane structure. Some applications to ligand-receptor and cell-cell interactions. In Surface Membrane Receptors: Interface between Cells and their Environment, pp. 1-24. Eds R. A. Bradshaw, N. A. Frazier, D. I. Gottlieb, R. C. Merrell \& R. A. Hogue-Angeletti. Plenum Press, New York.

SNeId, D.S., Jacobs, L.S., Weldon, V.V., TRIVedi, B.L. \& Daughaday, W.H. (1975) Radioreceptorinactive growth hormone associated with stimulated secretion in normal subjects. J. clin. Endocr. Metab. 41, $471-474$.

SöNKSEN, P.H. (Ed.) (1974) Radioimmunoassay and Saturation Analysis. (Br. med. Bull. 30.)

SutCliffe, H.S., Martin, T.J., Eisman, J.A. \& Pilczyk, R. (1973) Binding of parathyroid hormone to bovine kidney cortex plasma membranes. Biochem. J. 134, 913-921.

TaIT, S.A.S., Tait, J.F. \& Bradley, J.E.S. (1972) The effect of serotonin and potassium on corticosterone and aldosterone production by isolated zona glomerulosa cells of the rat adrenal cortex. Aust. J. exp. Biol. med. Sci. 50, 833-846.

Tsushima, T. \& Friesen, H.G. (1973) Radioreceptor assay for growth hormone. J. clin. Endocr. Metab. 37, 334-337.

Verrier, B., Fayet, G. \& Lissitzky, S. (1974) Thyrotropin-binding properties of isolated thyroid cells and their purified plasma membranes. Eur. $J$. Biochem. 42, 355-365.

WolfF, J. \& CoOKE, G.H. (1975) Charge effects in the activation of adenylate cyclase. J. biol. Chem. 250, 6897-6903.

Wolfsen, A.R., McIntyre, H.B. \& Odell, W.D. (1972) Adrenocorticotropin measurement by competitive binding receptor assay. J. clin. Endocr. Metab. 34, 684-689.

YALOW, R.S. \& BERSON, S.A. (1971) Problems of validation of radioimmunoassays. In Principles of Competitive Protein-Binding Assays, pp. 374-400. Eds W. D. Odell \& W. H. Daughaday. Lippincott, Philadelphia. 